\title{
KomUnikasi StrategiK dalam Pengurusan Komunikasi Organisasi: Definisi, Pendekatan dan Pelaksanaan
}

\author{
Muhammad Zaiamri Zainal Abidin \\ Universiti Malaya \\ zaiamrizainal@um.edu.my \\ Amira Firdaus \\ Universiti Malaya \\ amira_firdaus@um.edu.my \\ Md Azalanshah Md Syed \\ Universiti Malaya \\ azalan@um.edu.my
}

\section{ABSTRACT \\ STRATEGIC COMMUNICATION IN ORGANIZATIONAL COMMUNICATION MANAGEMENT: DEFINITION, APPROACH AND IMPLEMENTATION}

\begin{abstract}
Strategic communication is an effective communication of information distributions at every level includes individual, group and organization. In terms of organizational management, strategic communication defined as a purposeful communication in order to achieve a specific goal and target. Strategic communication does not only function as a tool of vision and goal interpretation towards targeted audience, but also to achieve both organization's vision and goal. It act as a centre to ensure a strategy implementation achievement made by the organization. This article will describe and discuss further strategic communication practices based on three focuses; definition, approach and implementation. Based on secondary data and analysis of the findings of previous studies as well as the views of scholars through the field of strategic communication research, It show that strategic communication is a purposeful communication practice managed systematically through planning, implementation and evaluation to achieve organization's goal and target which is practiced in six forms of approach includes management communication, marketing communication, public relations, technical communication, information communication, information and social marketing campaign in organizational communication.
\end{abstract}

Keywords: Strategic Communication, Organizational Communication Management, Targeted Audience, Internal Communication, External Communication 


\section{PENGURUSAN KOMUNIKASI ORGANISASI}

Pengurusan komunikasi merupakan aspek penting yang perlu dititikberatkan dalam tadbir urus sesebuah organisasi. Ini disebabkan kejayaan organisasi bergantung pada sejauh mana mesej organisasi itu dapat disalurkan dan disampaikan secara efektif kepada khalayak sasaran dalam membantu organisasi mencapai sesebuah misi serta matlamat yang telah ditetapkan. Miller dan Barbour (2014) menjelaskan komunikasi organisasi penting dalam memberi gambaran bagaimana sesebuah organisasi mempamerkan imej, kehadiran, mewujudkan suasana yang baik untuk pelaburan dan membentuk budaya organisasi yang bercirikan positif kepada khalayak mereka. Komunikasi organisasi ini secara asasnya berfungsi untuk melancarkan pelaksanaan tugas berkaitan peranan dan tanggungjawab yang spesifik seperti penjualan, perkhidmatan dan pengeluaran, membantu dari segi penyesuaian melalui kreativiti individu dan kumpulan, menyelenggara dasar, prosedur dan peraturan yang menyokong operasi harian, membangunkan hubungan antara organisasi dan individu menerusi sikap, moral, kepuasan, dan memenuhi tuntutan serta menyelaras, merancang dan mengawal operasi organisasi melalui pengurusan (McPhee \& Zaug, 2000). Oleh itu, komunikasi organisasi menyokong empat fungsi utama seperti informatif, ketetapan, pemujukan dan integrasi dalam pengurusan komunikasi organisasi.

Penyaluran komunikasi secara efektif tidak hanya membantu organisasi untuk menterjemahkan misi dan matlamat kepada para pekerja malahan menyumbang kejayaan untuk mencapainya. Hal ini disebabkan komunikasi organisasi bertindak sebagai pusat utama dalam memastikan kejayaan pelaksanaan sesuatu strategi yang dirangka oleh organisasi (Argenti et al., 2005). Shockley dan Pamela (2015) menerangkan bahawa komunikasi organisasi terbahagi kepada dua kategori iaitu komunikasi dalaman dan komunikasi luaran. Komunikasi dalaman ini dirujuk sebagai proses penyaluran komunikasi secara dalaman yang melibatkan dua pihak iaitu majikan dan golongan para pekerja. Terdapat empat jenis komunikasi dalaman yang dipraktikkan dalam organisasi yang meliputi komunikasi atasan ke bawah (downward communication), komunikasi bawahan ke atas (upward communication), komunikasi mendatar (horizontal communication) dan komunikasi lintas saluran (interline communication) (Miller, 2014).

Komunikasi atasan ke bawah merujuk pada proses komunikasi daripada pihak pengurusan kepada para pekerja berkaitan arahan kerja, rasional kerja, prosedur dan praktik kerja serta pemberian motivasi (Mintzberg, 1979). Berbeza dengan komunikasi bawahan ke atas yang menurut Miller (2014) melibatkan proses komunikasi daripada pihak pekerja kepada pihak majikan dan pengurusan meliputi penyampaian informasi berkaitan tugasan, maklum balas bagi penambahbaikan, dan keluhan para pekerja. Komunikasi mendatar pula meliputi proses komunikasi dalam kalangan para pekerja seperti pertukaran informasi, memperbaiki pembahagian tugas, penyelesaian masalah dan konflik serta membina perhubungan melalui aktiviti bersama (Miller, 2014), manakala bagi komunikasi lintas saluran ini terarah pada proses komunikasi yang melibatkan dua jabatan yang berbeza dan di luar rantaian komunikasi sedia ada. Kebiasaannya komunikasi lintas saluran ini perlu mendapat keizinan dan dipantau oleh pihak pengurusan atasan.

Komunikasi luaran pula melibatkan proses perhubungan antara organisasi dan khalayak luar. Khalayak luar meliputi golongan berkepentingan yang mempunyai urusan perniagaan dengan organisasi seperti pelanggan, pemegang taruh atau pemegang saham, media, masyarakat umum, pembekal, bank, badan berkanun dan pihak kerajaan (Shockley \& Pamela, 2015). Kedua-dua bentuk komunikasi organisasi ini boleh berlaku secara satu hala (monologic) atau dua hala (dialogic). Kelancaran kedua-dua aliran komunikasi ini penting untuk membina 
perhubungan dan interaksi secara bersama ahli dalaman organisasi dan khalayak luar. Oleh itu sesebuah organisasi perlu berkomunikasi secara efektif dan efisien agar mesej organisasi dapat disalurkan dan misi dan matlamat yang telah ditetapkan dapat dicapai.

Namun apakah proses yang boleh membantu organisasi untuk berkomunikasi secara efektif agar selari matlamat dan sasaran yang ingin dicapai? Holtzhausen (2014) menjelaskan sarjana perhubungan awam telah menerajui pelbagai kajian terhadap amalan komunikasi strategik bagi meninjau sejauh mana keberkesanan dan impak yang terhasil dalam pengurusan komunikasi organisasi. Pengkaji seperti Botan (1997), Steyn (2003), Argenti et al. (2005), Hallahan et al. (2007), Sandhu (2009) dan Houltzhausen (2014) menemukan komunikasi strategik begitu sinonim dan diguna pakai oleh organisasi atau entiti komunikatif kerana keberkesanannya menyebarkan komunikasi secara efektif, memelihara perhubungan secara berterusan dan membenarkan organisasi bekerja secara cekap untuk mencapai matlamat dan sasaran. Maka bagi mendalami secara lanjut, artikel ini akan mengkaji amalan komunikasi strategik dari perspektif pengurusan organisasi. Terdapat tiga aspek yang difokuskan merangkumi definisi, pendekatan dan pelaksanaan komunikasi strategi dalam konteks organisasi. Penyelidikan ini berpandu pada perolehan data sekunder dan analisis terhadap dapatan kajian lepas serta pandangan sarjana menerusi bidang penyelidikan komunikasi strategik.

\section{PENDEFINISIAN KOMUNIKASI STRATEGIK DALAM KONTEKS PENGURUSAN KOMUNIKASI ORGANISASI}

Terma "strategik" sering dikaitkan dengan amalan dan taktik yang digunakan bagi mengimplementasi strategi (Mintzberg, 1990). Menurut Hatch (1997) strategik dalam konteks organisasi merujuk kepada bagaimana organisasi bersaing bagi memperoleh kelebihan dan penguasaan dalam perkongsian pasaran. Begitu juga dengan komunikasi strategik dalam konteks yang sama dijelaskan tentang bagaimana organisasi atau entiti komunikator berkomunikasi secara bertujuan untuk mencapai misi dan matlamat (Holtzhausen, 2014). Komunikasi strategik suatu konsep komunikasi, proses, atau data yang memenuhi pelan jangka panjang organisasi menerusi perancangan yang teliti dengan menyelaraskan aktiviti komunikasi untuk tujuan perniagaan komersial dan bukan komersial. Dalam kata lain, komunikasi strategik dirujuk sebagai suatu proses komunikasi bertujuan yang dirancang, dilaksanakan, dan dinilai secara sistematik bagi mencapai sesuatu tujuan yang spesifik (Hallahan et al., 2007).

Sesuatu komunikasi dianggap strategik sekiranya selari dengan matlamat dan sasaran yang ditetapkan. Fokus komunikasi strategik ini adalah pada usaha organisasi memportret dan mempromosi entiti mereka menerusi aktiviti bertujuan sama ada oleh pemimpin, para pekerja dan pengamal komunikasi organisasi. Ini selari dengan sifat komunikasi strategik yang dinyatakan oleh Hallahan et al. (2007) sebagai komunikasi berbentuk penerangan, pemujukan, berubah-ubah dan pembinaan hubungan yang digunakan untuk mencapai matlamat organisasi.

Komunikasi strategik juga tidak terkecuali dikaitkan dengan penciptaan simbol menerusi amalan komunikasi yang dijalankan oleh organisasi secara luaran atau dalaman. Menurut Hallahan et al. (2007) dan Holtzhausen (2014), praktik komunikasi seperti perhubungan awam, periklanan dan pemasaran digunakan sebagai pendekatan dalam amalan komunikasi strategik yang bertindak sebagai strategi untuk mewujudkan simbol tertentu kepada khalayak sasaran. Aspek persimbolan atau perlambangan ini penting dalam mengukuhkan penjenamaan dan keterlihatan organisasi kepada khalayak mereka. Menerusi persimbolan ini 
organisasi mewujudkan perkongsian nilai secara bersama dengan khalayak sasaran menerusi komunikasi strategik yang dilaksanakan. Persimbolan ini dibentuk menerusi penggunaan saluran komunikasi yang sesuai, tepat dan berkesan yang membawa mesej organisasi secara jelas bagi menguasai perkongsian pasaran, pembinaan reputasi positif, memenangi kempen politik dan menguatkuasakan perubahan sosial. Ini menjadikan komunikasi strategik begitu efektif dalam menyalurkan maklumat dan mempengaruhi khalayak organisasi.

Perubahan persekitaran organisasi masa kini ekoran perkembangan teknologi dan segmen khalayak yang pelbagai memerlukan proses tadbir urus komunikasi dilakukan secara strategik. Oleh sebab itu organisasi perlu merancang dan melaksanakan komunikasi secara strategik agar mesej organisasi dapat disampaikan secara berkesan. Ini bertepatan dengan kebolehupayaan komunikasi strategik yang memberi peluang kepada organisasi untuk mencipta dan menyebarkan komunikasi dalam cara serta tujuan yang tersendiri kepada khalayak sasaran (Hallahan et al., 2007).

Komunikasi strategik disifatkan sebagai terancang dan proaktif yang tidak hanya digunakan oleh organisasi untuk mencapai misi dan matlamat, malahan mencegah sebarang krisis daripada berlaku. Ini dipengaruhi oleh kesedaran terhadap potensi komunikasi strategik yang berupaya membentuk informasi dan wacana umum dalam kalangan khalayak. Komunikasi strategik boleh memberi impak yang signifikan kepada khalayak sasaran dalam skala yang lebih besar. Para komunikator strategik boleh mempengaruhi kesan tempatan dan global terutamanya dalam aspek masyarakat berkaitan demokrasi, sistem politik dan pasaran berasaskan gender serta orientasi budaya. Untuk itu, pengaplikasian komunikasi strategik ini dapat dilihat dalam pelbagai bentuk komunikasi dan konteks kerana keupayaannya dalam mewujudkan sebaran komunikasi secara berkesan dalam skala kecil mahupun besar.

Namun perlu difahami juga amalan komunikasi strategik tidak menganjurkan konsep "linearity" atau bersifat monologic communication dalam proses pengurusan komunikasi (Botan, 1997). Sebagai contohnya, perspektif komunikasi tradisi memperlihatkan para komunikator lebih dominan mengawal mesej dan makna yang disalurkan kepada khalayak, tetapi situasinya agak berbeza dengan konsep komunikasi masa kini apabila mesej dan makna daripada proses komunikasi adalah sesuatu yang "negotiated" antara pengirim dengan penerima. Bahkan, penerima mesej juga boleh mempengaruhi makna dan mengawal kandungan komunikasi sama ada mahu menerima atau menolaknya. Ini bermakna proses dan kesan komunikasi masa kini juga bergantung pada golongan penerima. Ini menunjukkan bahawa elemen dialogic communication atau komunikasi secara dua hala menjadi sandaran utama dalam mewujudkan sebaran komunikasi secara berkesan seperti yang ditekankan dalam amalan komunikasi strategik. Ini disebabkan wujud kepercayaan bahawa komunikasi berkesan tidak hanya bersandar pada penggunaan saluran komunikasi yang tepat malahan perlu berlaku secara dua hala menerusi pembinaan perhubungan dan kepercayaan antara pengirim dan penerima mesej (Johannesen, 1996).

Oleh yang demikian, komunikasi strategik boleh dilihat sebagai komunikasi bertujuan yang dirangka dan dilaksanakan bagi mencapai misi dan matlamat organisasi. Amalan komunikasi strategik penting dalam konteks organisasi terutamanya untuk mewujudkan sebaran komunikasi secara berkesan sama ada dalam konteks komunikasi dalaman mahupun luaran menerusi proses pengurusan yang sistematik yang melibatkan perangkaan, pelaksanaan dan penilaian yang bersandarkan kepada misi dan matlamat yang telah ditetapkan oleh organisasi. Namun untuk memastikan keberkesanan amalan komunikasi strategik dapat 
dilakukan pada pelbagai peringkat terdapat beberapa pendekatan yang dianjurkan dalam pengurusan komunikasi organisasi. Walaupun begitu, apakah bentuk-bentuk pendekatan yang dimaksudkan?

\section{APLIKASI PENDEKATAN DALAM KOMUNIKASI STRATEGIK}

Hallahan et al. (2007) menjelaskan komunikasi strategik diaplikasikan menerusi pelbagai pendekatan dalam pengurusan komunikasi organisasi. Pendekatan yang dinyatakan ini berfungsi membantu organisasi untuk menyebarkan mesej organisasi secara berkesan pada pelbagai peringkat. Sebagai komunikasi bertujuan, amalan komunikasi strategik ini dipengaruhi oleh matlamat dan segmen khalayak yang ingin difokuskan oleh organisasi. Setiap pendekatan mempunyai tujuan dan fokus komunikasi yang berbeza. Terdapat enam pendekatan utama yang dipraktikkan oleh organisasi menerusi amalan komunikasi strategik yang merangkumi komunikasi pengurusan, komunikasi pemasaran, perhubungan awam, komunikasi teknikal, komunikasi politik dan kempen informasi/ pemasaran sosial.

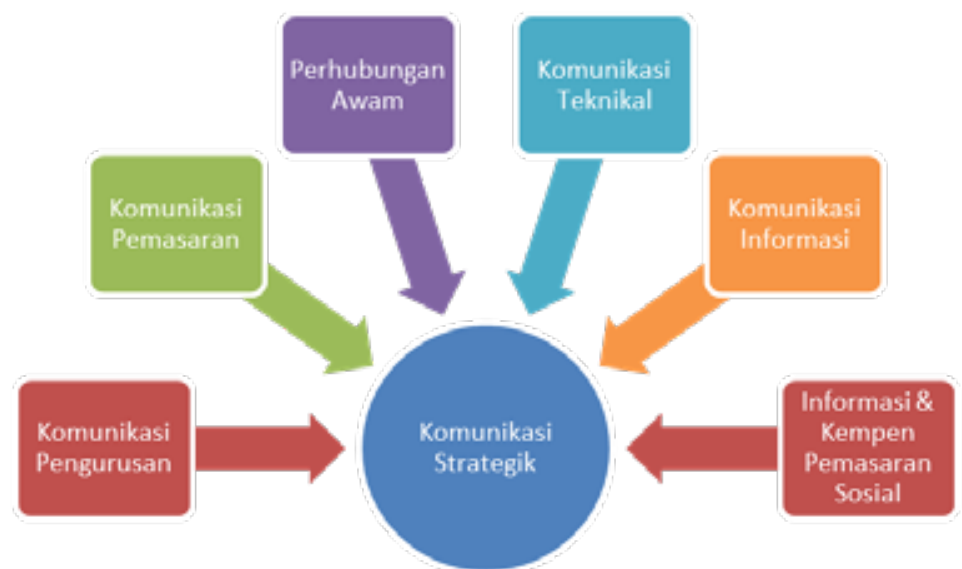

Rajah 1: Enam Pendekatan Utama Komunikasi Strategik dalam Pengurusan Organisasi oleh Hallahan et al. (2007) dan Holtzhausen (2014).

Komunikasi pengurusan memberi tumpuan terhadap aspek pengurusan dan pentadbiran secara keseluruhannya (Argenti et al., 2005). Tujuan utama pendekatan komunikasi pengurusan diperkenalkan adalah untuk mengawal selia bagi memudahkan operasi organisasi secara teratur. Selain itu, komunikasi pengurusan juga memainkan peranan dalam mempromosi pemahaman mengenai misi, visi dan matlamat organisasi dan membekalkan maklumat bagi keperluan operasi hari ke hari merangkumi perihal pelanggan, transaksi vendor dan pelanggan, serta latihan kepada para staf (Hallahan et al., 2007).

Pendekatan kedua merupakan komunikasi pemasaran yang melibatkan aktiviti staf di bahagian pemasaran dan periklanan. Fokus utama komunikasi pemasaran ini adalah untuk mewujudkan kesedaran dan mempromosi penjualan produk/perkhidmatan di samping menarik minat dan mengekalkan pengguna/pelanggan termasuk perantara dalam saluran pengedaran (Argenti et al., 2005). Bagi pertubuhan bukan kerajaan dan organisasi bebas keuntungan, komunikasi pemasaran menggabungkan aktiviti pengumpulan dana dan pembangunan komunikasi. 
Seterusnya adalah perhubungan awam yang bertindak sebagai salah satu pendekatan yang diimplementasikan dalam amalan komunikasi strategik organisasi. Pendekatan ini secara khususnya memfokuskan aktiviti komunikasi yang melibatkan staf di beberapa bahagian seperti publisiti dan perhubungan awam, sumber manusia, kewangan dan perhubungan kerajaan (Hallahan et al., 2007). Fungsi utama pendekatan ini adalah untuk menubuh dan mengekalkan manfaat bersama pihak berkepentingan. Ini merangkumi pengguna dan pelanggan, begitu juga dengan pelabur dan penderma, pekerja dan sukarelawan, ketua komuniti dan pegawai kerajaan.

Selain itu, pendekatan komunikasi teknikal turut tidak dikecuali dilaksanakan menerusi amalan komunikasi strategik dalam konteks pengurusan organisasi. Komunikasi teknikal ini melibatkan pengurusan staf di bahagian teknikal, sokongan kejuruteraan dan staf pelatih (Argenti et al., 2005). Tujuan utamanya adalah untuk mendidik para pekerja, pelanggan dan individu lain yang terlibat untuk menambahbaik dari segi meningkatkan kecekapan mereka. Ini meliputi pengurangan kesalahan / kesilapan dan mempromosi keberkesanan penggunaan teknologi terutama dalam melaksanakan tugasan penting untuk organisasi.

Pendekatan kelima pula merupakan komunikasi politik yang melibatkan kelompok pengurusan organisasi seperti pegawai perhubungan kerajaan, ahli politik dan golongan penyokong. Komunikasi politik ini khususnya memfokuskan pembinaan persetujuan politik dan perakuan terhadap isu semasa berkaitan penguasaan politik dan pengagihan sumber terhadap masyarakat (Hallahan et al., 2007). Pendekatan komunikasi ini turut merangkumi usaha mempengaruhi pengundian dalam pilihanraya dan juga keputusan polisi masyarakat oleh pembuat undang-undang serta pihak pengurusannya manakala di peringkat antarabangsa, komunikasi politik ini lebih tertumpu kepada perihal komunikasi untuk menyokong diplomasi publik dan kestabilan ketenteraan.

Pendekatan komunikasi strategik yang terakhir pula menyentuh mengenai pengurusan komunikasi dalam aspek informasi dan kempen pemasaran sosial dalam organisasi. Komunikasi informasi dan kempen pemasaran sosial ini lebih memfokuskan pengurusan oleh golongan kakitangan bukan kerajaan, organisasi bebas keuntungan, agensi kerajaan terutama kakitangan yang terlibat dengan aspek sosial, psikologi dan kesejahteraan fizikal (Argenti et al., 2007). Komunikasi di peringkat ini lebih bertujuan untuk mengurangkan insiden berkaitan kelakuan berisiko dan pada masa yang sama juga ingin mempromosi kepentingan akibat sosial demi kebaikan komuniti (Hallahan et al., 2007).

Setiap pendekatan memainkan peranan yang tersendiri kepada organisasi dalam membawa pengaruh komunikasi tertentu mengikut tujuannya yang tersendiri. Sebaran komunikasi secara strategik ini dipraktikkan dalam pelbagai pendekatan oleh bahagian/jabatan tertentu bagi memenuhi keperluan organisasi di setiap peringkat. Pengaplikasian dan praktik komunikasi strategik boleh berlaku dalam kepelbagaian sudut serta fokus yang bersandarkan kepada misi dan matlamat yang ingin dicapai oleh organisasi. Setiap pendekatan ini penting dalam proses perencanaan aktiviti komunikasi organisasi secara keseluruhan.

\section{PROSES PENGURUSAN KOMUNIKASI STRATEGIK}

Komunikasi strategik dalam konteks organisasi seringkali dikaitkan dengan aktiviti komunikasi bertujuan yang terancang dan sistematik. Ini disebabkan organisasi melihat komunikasi strategik sebagai strategi yang melibatkan proses pembuatan keputusan secara rasional dalam 
memenuhi misi, visi dan matlamat organisasi. Analisis SWOT menjadi asas utama dalam pelaksanaan komunikasi strategik yang meliputi proses seperti penetapan agenda, formulasi strategi, implementasi dan penilaian dalam pengurusan komunikasi organisasi (Porter, 1985). Hal ini selari dengan pandangan Holtzhausen (2014) yang menjelaskan komunikasi strategik sebagai suatu proses rasional yang bermula dengan analisis terhadap kekuatan dan kelemahan serta peluang dari luar dan ancaman terhadap organisasi. Analisis SWOT ini digunakan untuk menentukan matlamat organisasi, objektif, strategi dan taktik.

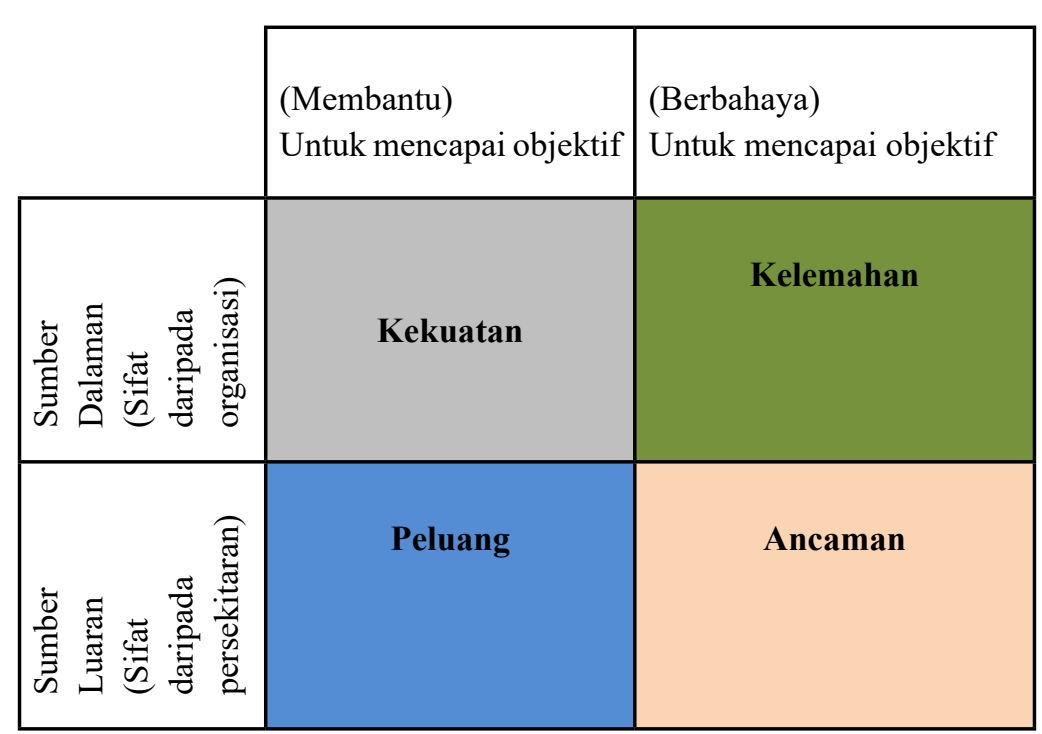

\section{Rajah 2: Analisis SWOT dari perspektif Komunikasi Strategik (Diadaptasi daripada konsep Strength, Weakness, Opportunities, and Threaten oleh Humphrey, A., 1960 \& 1970)}

Seterusnya, peranan komunikator organisasi lebih tertumpu pada mereplika proses tersebut dengan fokus bagaimana komunikasi boleh digunakan secara strategik untuk menyokong dan memenuhi matlamat organisasi. Komunikasi strategik ini mempunyai atur cara atau proses tersendiri dalam mengurus komunikasi organisasi. Ini melibatkan aturan seperti perancangan, pelaksanaan dan penilaian terhadap aktiviti komunikasi yang dijalankan oleh organisasi (Hallahan et. al, 2007).
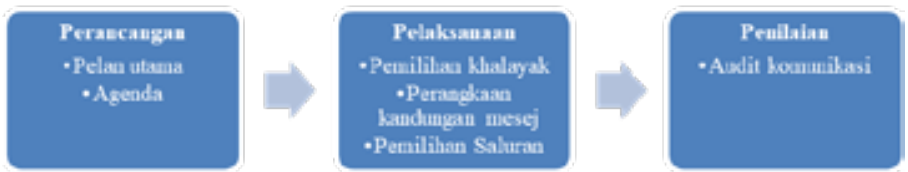

Rajah 3: Fasa dalam pengurusan komunikasi strategik oleh Hallahan et al. (2007)

Perancangan komunikasi ini melibatkan dua proses iaitu perangkaan pelan utama dan agenda yang ditetapkan oleh organisasi. Pelan utama ini secara khususnya memberi tumpuan terhadap organisasi, perkhidmatan dan produk, panduan rangka kerja untuk pengurus dan kakitangan 
melaksanakan tugas dengan cekap, dan mengadvokasi dasar, peraturan dan undang-undang yang menjadi kerangka operasi mereka (Patterson \& Radtke, 2009). Agenda pula merujuk kepada sebaran komunikasi dan mesej kepada khalayak melalui mesej terpilih yang lebih spesifik menerusi saluran yang efektif bagi mewujudkan kesedaran dan kefahaman kepada khalayak mengenai visi, matlamat dan misi organisasi (Mahbob et al., 2019). Pelan komunikasi strategik organisasi ini secara khususnya mempunyai tiga peringkat masa iaitu pelan jangka masa pendek, sederhana dan jangka masa panjang. Pelan komunikasi strategik ini penting dalam membantu organisasi mengagihkan sumber secara efektif dan strategik agar dapat mengubah budaya organisasi ke arah kecekapan komunikasi memandangkan setiap aktiviti organisasi mempunyai perkaitan dengan komunikasi (Hallahan et al., 2007).

Aturan kedua pula meliputi aspek pelaksanaan dalam proses pengurusan komunikasi secara strategik (Holtzhausen \& Zerfasss, 2013). Secara khususnya pelaksanaan komunikasi ini memberi fokus dalam menjalankan strategi komunikasi yang dirancang secara teliti mengikut jangka masa yang telah ditetapkan. Dalam peringkat pelaksanaan komunikasi strategik ini terdapat beberapa aspek diberi penekanan seperti pemilihan khalayak yang sesuai selaras dengan objektif yang telah dipilih. Seterusnya pula, memberi keutamaan terhadap perangkaan kandungan mesej yang selaras dengan objektif dan pada masa yang sama menangani jurang maklumat yang boleh menganggu-gugat penerimaan mesej terhadap khalayak sasaran. Begitu juga dengan pemilihan dan penggunaan saluran komunikasi atau media yang perlu menjamin keberkesanan penyampaian kepada khalayak dan selaras dengan strategi yang diguna pakai. Selain itu, penyelarasan dan kerjasama dengan pihak berkepentingan tidak terkecuali memainkan peranan bagi memastikan aktiviti komunikasi yang dilaksanakan lebih cekap dan mesej dapat disampaikan secara berkesan (Baltic Marine Environment Protection Commission, 2014).

Aturan yang terakhir memfokuskan aspek penilaian komunikasi bagi tujuan penambahbaikan kepada strategi komunikasi yang dilaksanakan oleh organisasi. Antara salah satu proses penilaian yang dilakukan terhadap aktiviti komunikasi strategik adalah menerusi audit komunikasi (Mahbob et al., 2019). Audit komunikasi ini khususnya memberi tumpuan dalam menganalisis keberkesanan pelan dan pelaksanaan komunikasi yang telah dijalankan oleh organisasi. Menerusi penilaian yang dilakukan ini organisasi dapat mengenal pasti faktor yang mempengaruhi keberkesanan komunikasi dan elemen lain yang membatasinya. Oleh itu, aspek penilaian dapat membantu organisasi untuk memperbaiki kelemahan sedia ada sebagai usaha untuk membina pelan dan kaedah komunikasi yang lebih berkesan kepada khalayak organisasi.

Berdasarkan penerangan berikut, jelas bahawa komunikasi strategik merupakan suatu proses pengurusan komunikasi yang bersifat strategik dan sistematik yang dijalankan oleh organisasi. Hal ini dipastikan menerusi pengaplikasian analisis SWOT yang memanfaatkan kekuatan, kelemahan, ancaman dan peluang yang wujud dalam melaksanakan aktiviti komunikasi yang boleh menyumbang pada capaian misi dan matlamat organisasi. Dengan itu, organisasi dapat merangka matlamat, objektif, strategi dan taktik komunikasi yang selari dengan kehendak dan keperluan mereka. Begitu juga dalam memastikan kelancaran komunikasi yang menjadi salah satu penekanan utama menerusi amalan komunikasi strategik yang berteraskan kepada perancangan, pelaksanaan dan penilaian. Ini menjadikan komunikasi strategik begitu efektif digunakan dalam capaian misi dan matlamat organisasi ekoran daripada keupayaan dalam mewujudkan sebaran komunikasi secara berkesan menerusi sifatnya 
yang strategik dan sistematik. Walaupun begitu, terdapat rasionalisasi tersendiri di sebalik pelaksanaan komunikasi strategik kepada organisasi.

\section{RASIONALIASASI PELAKSANAAN KOMUNIKASI STRATEGIK DALAM KONTEKS ORGANISASI}

Persekitaran memainkan peranan yang penting dalam mempengaruhi kaedah dan strategi komunikasi yang dipraktikkan oleh sesebuah organisasi. Perubahan yang berlaku dalam ekosistem masyarakat yang melibatkan sistem ekonomi, undang-undang politik, sosiobudaya, daya saing dan segmen teknologi saban tahun ini telah mengubah cara mereka berkomunikasi. Gilpin dan Murphy (2008) menjelaskan apabila berlaku perubahan dan perkembangan kaedah komunikasi dalam kalangan masyarakat umum, komunikasi organisasi juga perlu dilaksanakan secara strategik. Pandangan ini selari dengan penjelasan Tina Dacin et al. (2002) dan Sandhu (2009) yang menghubungkaitkan institutional theory oleh Scott (2004) dan ecology theory oleh Mcluhan (1962) bahawa persekitaran juga memainkan peranan dalam menentukan kelangsungan sesebuah organisasi. Untuk itu, komunikasi strategik dilihat dapat membantu organisasi dari segi pengadaptasian dengan perubahan persekitaran yang berlaku masa kini.

Terdapat empat rasionalisasi utama antaranya pertama seperti melibatkan tarikan kemampuan komunikator masa kini yang lebih tertumpu untuk merangka dan melaksanakan aktiviti komunikasi organisasi yang lebih bersifat strategik atau terarah. Walaupun pengaplikasian komunikasi pemasaran bersepadu yang memberi tumpuan bagi mengkoordinasi gabungan pelbagai fungsi komunikasi dalam pengurusan organisasi, keupayaannya seakan mula perlu dikaji semula (Hallahan et al. 2007). Hal ini kerana terdapat kesedaran terhadap perubahan saluran komunikasi khalayak ekoran daripada perkembangan media dan teknologi yang berlaku dalam sistem perhubungan masyarakat (Grunig \& Grunig 2008). Jika terdahulu pengurusan komunikasi organisasi lebih menumpukan penggunaan media daripada komposisi yang pelbagai, namun penggunaannya masa kini harus ke arah yang strategik. Memandangkan terdapat pengurangan keberkesanan media tertentu dalam menyalurkan komunikasi organisasi kepada khalayak sasaran. Ini menggalakkan para komunikator organisasi masa kini memfokuskan perancangan komunikasi yang lebih bersifat strategik dan teliti agar sebarannya dapat dilakukan secara berkesan menggunakan saluran atau medium komunikasi yang sesuai dan tepat.

Rasionalisasi kedua pula melibatkan perubahan penting dalam komunikasi masyarakat yang dipandu oleh perkembangan teknologi dan ekonomi media (Grunig\& Grunig, 2008). Pengenalan teknologi digital seperti jaringan sejagat dan pesanan ringkas telah menggerakkan kepelbagaian dalam aktiviti komunikasi seperti periklanan, publisiti, promosi jualan dan e-dagang. Di sini jelas menunjukkan bagaimana teknologi menyatukan saluran komunikasi dan mempelbagaikan kaedah perhubungan masyarakat yang terdiri daripada pelbagai lapisan. Situasi ini menuntut satu bentuk perancangan komunikasi yang teratur atau strategik oleh organisasi untuk menyasarkan mesej bertujuan kepada khalayak sasaran. Ini boleh membantu organisasi dari segi menyelenggara komunikasi secara efektif dan bertindak sebagai pemudahcara dalam proses perhubungan bersama khalayak sasaran.

Rasionalisasi ketiga dikaitkan dengan perkembangan organisasi yang mula memperluas kepelbagaian kaedah dalam mempengaruhi kumpulan khalayak sasaran (Holmstrom, 2005). Ini meliputi penelitian secara mendalam terhadap apa-apa yang diketahui oleh khalayak sasaran, perasaan mereka dan bagaimana tindak balas mereka terhadap organisasi. Situasi 
ini membantu organisasi untuk mengenal pasti dan meninjau sejauh mana keberkesanan aktiviti komunikasi yang dijalankan serta melakukan proses penambahbaikan dalam mengurus komunikasi organisasi. Dengan itu, aktiviti komunikasi dapat dirangka secara strategik dengan menggunakan variasi saluran komunikasi agar capaiannya meliputi khalayak daripada pelbagai peringkat. Hal ini penting dalam mempertimbangkan aktiviti komunikasi organisasi daripada perspektif strategik dan integratif / bersepadu.

Rasionalisasi yang terakhir pula dikaitkan dengan saranan komunikasi strategik yang menekankan pengaruh bertujuan merupakan matlamat asas komunikasi kepada organisasi. Pengaruh bertujuan ini boleh dirujuk sebagai sebaran komunikasi yang dirangka dan dilaksanakan mengikut misi dan matlamat yang ingin dicapai oleh organisasi (Hallahan et al. 2007). Ini merangkumi pelaksanaan aktiviti komunikasi yang boleh mempengaruhi khalayak sasaran menerusi mesej organisasi yang disebarkan. Maka untuk memastikan aktiviti komunikasi yang dijalankan selari ini dengan misi dan matlamat organisasi dan boleh memberi pengaruh yang kuat kepada khalayak sasaran, komunikasi strategik menganjurkan proses komunikasi yang diuruskan secara sistematik. Sistematik yang dimaksudkan melibatkan tiga proses utama merangkumi perancangan, pelaksanaan dan penilaian bagi memastikan aktiviti komunikasi organisasi yang dijalankan lebih bersifat spesifik dan strategik. Proses ini bermula dengan penetapan matlamat dan seterusnya analisis khalayak, kemudiannya merangka strategi mesej dan langkah seterusnya melakukan pemilihan saluran media serta di peringkat akhir melakukan program penilaian terhadap aktiviti komunikasi yang dijalankan (Porter, 1985; Argenti et al., 2005). Ini bagi memastikan aktiviti komunikasi yang dijalankan selari dengan tujuan penyampaiannya dan dapat disebar secara efektif kepada khalayak sasaran serta penilaian dapat dilakukan oleh organisasi sepanjang proses komunikasi berlangsung.

Terdapat empat faktor yang mempengaruhi rasionalisasi di sebalik pengaplikasian komunikasi strategik dalam pengurusan organisasi. Ini dikaitkan dengan rangkuman faktor seperti penawaran fungsi komunikasi strategik, memenuhi tuntutan perubahan dalam sistem perhubungan masyarakat, seiring dengan keperluan komunikasi organisasi masa kini dan penekanan terhadap prinsip komunikasi bertujuan yang disebar secara efektif yang menggalakkan pengaplikasian komunikasi strategik dalam membantu organisasi mencapai misi dan matlamat yang ditetapkan. Lantas ini membuatkan organisasi cenderung mempraktikkan amalan komunikasi strategik sebagai usaha untuk memastikan mesej organisasi dapat disebar secara efektif, menggunakan saluran yang tepat dan capaiannya mampu menembusi pelbagai lapisan masyarakat.

\section{KAJIAN KES PENGGUNAAN KOMUNIKASI STRATEGIK DALAM KONTEKS ORGANISASI}

Dalam memahami peranan komunikasi strategik, terdapat beberapa rangkuman kajian kes yang dijalankan bagi meninjau keberkesanan pelaksanaan komunikasi bertujuan dalam konteks organisasi antaranya yang pertama ialah peranan penggunaannya dalam pembentukan reputasi korporat. Kajian dalam fokus ini dilakukan oleh pengkaji seperti Morsing (2006), Unerman, (2008), Capriotti (2011), Amaladoss dan Manohar(2013), Kim (2014), Cho, Furey, dan Mohr, T. (2016), Ajayi, dan Mmutle (2020) yang meneroka penggunaan komunikasi strategik menerusi pelaksanaan Kempen Tanggungjawab Sosial. Berdasarkan rangkuman kajian ini, jelas bagaimana organisasi memfokuskan penggunaan strategi komunikasi dan pemilihan media yang sesuai dalam mewujudkan sebaran komunikasi secara berkesan kepada khalayak sasaran 
melalui kempen-kempen Tanggungjawab Sosial yang dijalankan. Dengan sebaran komunikasi secara berkesan ini organisasi memanfaatkannya dalam membentuk imej dan reputasi yang positif kepada khalayak organisasi.

Begitu juga dengan pengaplikasian komunikasi strategik oleh agensi kerajaan dalam konteks didikan kepada khalayak umum. Terdapat beberapa pengkaji seperti Thomas (2007), Lixin, dan Tahira (2016), Lucic, Barbic, dan Markoja, (2020), Tasiu Abubakar (2017), Lucic, Barbic, dan Markoja, (2020) dan Ogbuleke (2020) yang mengetengahkan penggunaan komunikasi strategik untuk pendidikan khalayak umum berkaitan penyebaran ilmu dan pemupukan sikap yang positif. Ini merangkumi didikan terhadap pencegahan keganasan, keselamatan nasional, simpanan kewangan pencen dan isu-isu ketenteraan. Kajian dalam konteks ini memperincikan strategi dan pelaksanaan aktiviti serta kempen media strategik yang dijalankan oleh agensiagensi kerajaan bagi proses didikan khalayak dalam penyebaran ilmu dan pembentukan nilai serta sikap yang positif.

Seterusnya pula penggunaan komunikasi strategik dalam sektor pendidikan tinggi seperti universiti dalam membina hubungan yang positif dengan pemegang taruh yang terlibat. Kajian dalam skop ini memperlihatkan fungsi dan peranan komunikasi strategik yang dilaksanakan menerusi penggunaan medium seperti media sosial, laman web dan interactive stakeholder engagement tools dalam proses pembinaan hubungan bersama pemegang taruh universiti. Ini termasuklah bagi tujuan memastikan keterlihatan organisasi, mempromosi perkhidmatan dan produk pendidikan tinggi, meneroka tahap aktiviti yang dijalankan serta menganalisis respons pemegang taruh. Berdasarkan kajian dalam skop ini menjelaskan bahawa komunikasi strategik tidak hanya berfungsi dalam mewujudkan sebaran komunikasi organisasi secara berkesan semata-mata, malahan berupaya dalam membina hubungan yang positif antara universiti dan pemegang taruh serta mempromosi organisasi secara keseluruhan. Kajian dalam skop ini dilakukan oleh para pengkaji seperti Lee, Park, dan Cameron, (2018), Fahnrich, Vogelgesang, dan Scharkow, (2020), Farinloye, Wayne, Mogaji, dan Kuika Watat, (2020), Mogaji, Watat, Olaleye, dan Ukpabi (2021).

Menerusi perincian terhadap rangkuman kajian kes ini jelas memperlihatkan bagaimana komunikasi strategik boleh diaplikasikan dalam pelbagai bidang dan tujuan. Ini menunjukkan bahawa komunikasi strategik tidak hanya berupaya mewujudkan sebaran komunikasi secara berkesan semata-mata, malahan pelaksanaannya dapat disesuaikan dan diadaptasi mengikut keperluan dalam menyampaikan mesej organisasi. Dengan itu, kita dapat mendalami fungsi komunikasi strategik sebagai komunikasi bertujuan yang dinamik digunakan secara efektif oleh organisasi untuk mencapai misi dan matlamat menerusi pengaplikasiannya dalam konteks yang pelbagai.

\section{PERBINCANGAN}

Berdasarkan penjelasan di atas, komunikasi strategik dapat difahami dari perspektif definisi, pendekatan dan pelaksanaannya dalam konteks pengurusan komunikasi organisasi. Komunikasi strategik boleh diklasifikasikan sebagai suatu bentuk kegiatan atau aktiviti komunikasi terancang yang dijalankan oleh organisasi dengan tujuan untuk mencapai sesuatu misi dan matlamat. Secara asasnya komunikasi strategik ini berfungsi sebagai alat yang membantu organisasi untuk menyebarkan komunikasi bertujuan secara berkesan kepada khalayak sasaran sama ada di dalam atau di luar organisasi. Sebaran komunikasi 
secara berkesan ini berlaku disebabkan penekanan terhadap proses yang terkandung dalam pengurusan komunikasi strategik.

Ini dijelaskan oleh Holtzhausen (2014) menerusi kajiannya bahawa komunikasi strategik merupakan proses perancangan bersifat rasional yang melibatkan analisis secara mendalam terhadap kekuatan dan kelemahan organisasi serta menilai peluang luaran dan ancaman yang bakal dihadapi bagi merangka kempen dan aktiviti komunikasi organisasi. Proses analisis ini membantu organisasi untuk merangka matlamat dan objektif serta membentuk strategi dan taktik komunikasi yang bakal dilaksanakan untuk mencapai kedua-dua fokus berikut. Dengan itu, kita dapat melihat bagaimana pengamal atau pengurus komunikasi organisasi mereplikakan proses tersebut menggunakan saluran komunikasi secara strategik bagi mencapai matlamat dan objektif yang ditetapkan oleh organisasi.

Dalam menganalisis keberkesanan komunikasi strategik dalam pengurusan organisasi, terdapat empat faktor yang dikenalpasti menjadi kekuatan utama antaranya yang pertama ialah aktiviti yang dijalankan adalah bersifat strategik. Pandangan ini dipersetujui oleh Botan (1997), Hatch (1997), Argenti (2005), Hallahan et al. (2007), Sandhu (2009), Van Ruler, B. (2018), dan Verhoeven et al. (2020) yang menyifatkannya sebagai komunikasi yang sejajar dengan strategi organisasi bagi tujuan meningkatkan kedudukan strategik. Ini boleh difahami menerusi penerapan konsep komunikasi bertujuan dalam pengurusan organisasi di mana aktiviti yang dijalankan adalah berpandu kepada matlamat dan objektif yang telah ditetapkan. Komunikasi strategik ini dilaksanakan mengikut strategi dan taktik yang berasaskan tujuan penyampaiannya. Hal ini menjadikan aktiviti komunikasi yang dijalankan oleh organisasi lebih terarah dan spesifik kepada khalayak sasaran. Bahkan, ini turut mempengaruhi proses penghasilan kandungan dan pemilihan media yang seiring dengan tujuan penggunaan serta kesesuaian khalayak yang ingin disasarkan oleh organisasi. Ini membuatkan aktiviti komunikasi yang dijalankan mampu memberi kesan efektif kepada khalayak sasaran yang akhirnya membantu dalam proses capaian misi dan matlamat organisasi.

Faktor kedua pula dikaitkan dengan praktik pengurusan disifatkan terancang dan sistematik yang berupaya menjamin keberkesanan sebaran komunikasi kepada organisasi. Kebanyakan penyelidik seperti Porter (1985), Hatch (1997), Hallahan et al. (2007), Patterson dan Radtke (2009), Holtzhausen dan Zerfasss (2013) serta Mahbob et al. (2019) turut mengakui bahawa komunikasi strategik mempunyai kekuatan dari segi atur cara pengurusannya yang melibatkan proses pembuatan keputusan secara rasional. Dengan itu, kita dapat melihat analisis SWOT digunakan dalam proses penetapan agenda, formulasi strategi, implementasi dan penilaian dalam melaksanakan komunikasi organisasi. Bagi memastikan sebaran komunikasi secara berkesan berlaku dan sejajar dengan matlamat yang ingin dicapai, terdapat tiga fasa yang diterapkan dalam pelaksanaan komunikasi strategik yang meliputi perancangan, pelaksanaan dan penilaian. Ketiga-tiga fasa ini penting untuk mewujudkan kelancaran dan keberkesanan terhadap aktiviti komunikasi yang dijalankan oleh organisasi.

Faktor ketiga adalah disebabkan keberkesanan komunikasi strategik dalam mencipta makna. Tidak dapat dinafikan komunikasi sering dikaitkan dengan proses penciptaan makna, begitu juga dengan peranan komunikasi strategik dalam pengurusan organisasi. Ini diakui oleh pengkaji seperti Hatch (1997) dan Hallahan (2007) yang menjelaskan komunikasi strategik juga melibatkan proses di mana entiti berusaha berkomunikasi dengan mencipta dan berkongsi makna secara bersama dengan khalayak sasaran. Makna ini dicipta dengan menggunakan pendekatan secara psikologi, sosial dan budaya bagi membentuk mesej organisasi yang mudah difahami dan diterima oleh khalayak sasaran. Makna ini juga boleh 
dijelaskan menerusi bagaimana kita memahami, menjelaskan, merasai dan bertindak balas terhadap sesuatu perkara (Ronsengren, 2000). Perkongsian makna ini penting terutamanya dalam membina, memperkuat dan mengekalkan perhubungan antara organisasi dan khalayak sasaran menerusi aktiviti komunikasi yang dijalankan. Ini menjadikan komunikasi strategik begitu efektif digunakan untuk menyebarkan mesej organisasi dan mempengaruhi khalayak sasaran menerusi perkongsian makna yang diwujudkan.

Faktor terakhir pula dikaitkan dengan pemilikan sifatnya yang dinamik. Dinamik yang dimaksudkan ini tertumpu pada kemampuan komunikasi strategik untuk menyesuaikan, menerbitkan pembaharuan dan kemajuan dengan segala bentuk perubahan komunikasi yang berlaku masa kini. Komunikasi strategik ini pada asasnya memiliki keupayaan daripada segi penyesuaian pelaksanaannya dalam pelbagai konteks pengurusan organisasi. Ini dapat dilihat apabila komunikasi strategik dilaksanakan secara berkesan menerusi beberapa pendekatan komunikasi organisasi seperti komunikasi pengurusan, komunikasi pemasaran, perhubungan awam, komunikasi teknikal, komunikasi politik dan informasi / kempen pemasaran sosial. Hal ini terdorong oleh sifat semula jadi komunikasi strategik yang diklasifikasikan oleh Botan (1997), Hallahan (2007), Sandhu (2014) sebagai informatif, meyakinkan, sering berubah dan sebagai komunikasi perhubungan yang digunakan dalam konteks pencapaian matlamat dan sasaran organisasi. Tambahan lagi menurut Hallahan (2007) pengenalan komunikasi strategik (selaras sifatnya yang dinamik) sebagai salah satu fungsi disiplin komunikasi menepati keperluan persekitaran pascamoden yang berlaku pada abad ke-21 masa kini yang memberi penekanan terhadap pendekatan menyeluruh dalam menilai fenomena organisasi serta pada masa yang sama perlu menghadapi pecahan khalayak dan platform komunikasi. Ini menjadikan komunikasi strategik efektif digunakan oleh organisasi untuk mencapai misi dan matlamat walaupun terdapat perubahan dalam ekosistem komunikasi masa kini.

Walaupun terdapat kekuatan yang menyokong penggunaan komunikasi strategik dalam pengurusan organisasi, namun terdapat beberapa kritikan terhadap penggunaannya. Ini meliputi kritikan seperti manipulasi organisasi menerusi komunikasi strategik terhadap khalayak sasaran. Pandangan ini turut dipersetujui oleh pengkaji seperti Pfeffer dan Salancik (1978) yang berpandangan perancangan strategik adalah satu bentuk usaha organisasi untuk menguasai persekitaran dan mengekalkan autonomi mereka. Tambahan lagi menurut Hallahan (2007) terdapat segelintir sarjana komunikasi yang mengkritik komunikasi strategik sebagai proses manipulasi persekitaran oleh organisasi menerusi sumber sedia ada bagi memperoleh keuntungan tersendiri tanpa mengambil kira kepentingan pihak lain seperti pemegang taruh, constituencies, dan kebimbangan komunikasi khalayak secara umum. Walaupun komunikasi strategik dianggap sebagai manipulasi yang digunakan untuk mencapai matlamat dan sasaran, namun organisasi turut menitikberatkan aspek perkongsian makna secara bersama dengan khalayak sasaran. Menerusi perkongsian makna ini, organisasi memberi perhatian terhadap apa-apa yang diketahui oleh khalayak, bagaimanakah perasaan mereka, dan tindak balas khalayak terhadap organisasi dalam merangka strategi komunikasi yang membentuk persefahaman secara bersama. Situasi ini serba sedikit menyumbang kepada usaha organisasi untuk meneliti keperluan khalayak sasaran dan cuba untuk memenuhinya bagi membina perhubungan berterusan secara bersama menerusi komunikasi strategik yang dilaksanakan.

Begitu juga dengan kritikan seterusnya yang melihat komunikasi strategik sebagai penguasaan komunikasi satu hala atau asymmetrical communication oleh organisasi ekoran daripada tujuan asal komunikasi dilaksanakan tertumpu untuk mempengaruhi khalayak sasaran. Walaupun komunikasi strategik memberi ruang komunikasi secara dua hala, terdapat 
perspektif yang melihat bentuk komunikasi ini sebagai pemujukan saintifik secara tersirat oleh organisasi untuk mencapai matlamat dan sasaran mereka. Kritikan terdapat pendekatan komunikasi ini turut menyentuh orientasi yang lebih tertumpu kepada pengirim atau organisasi dan mengabaikan peranan penting penerima. Namun begitu, komunikasi strategik secara khususnya tidak hanya dominan kepada organisasi semata ini kerana terdapat dua model komunikasi utama yang terkandung dalam amalan tersebut. Ini merangkumi model komunikasi transmisi dan model komunikasi interaktif yang dilaksanakan dalam amalan komunikasi strategik oleh organisasi (Grunig 1976, 1989, 2001). Kedua-dua model ini memberi penekanan berbeza dari segi atur cara pengurusan komunikasi di mana model komunikasi transmisi lebih tertumpu kepada pelepasan maklumat sehala manakala model komunikasi interaktif pula melibatkan penciptaan dan pertukaran makna antara kedua-dua pihak dalam aktiviti komunikasi.

Model komunikasi transmisi dilihat lebih mendapat kritikan kerana tertumpu kepada komunikasi satu hala di mana organisasi memfokuskan transmisi mesej menerusi saluran dengan kapasi limitasi tindak balas. Berbeza dengan model komunikasi interaktif yang menekankan prinsip symmetrical communication atau komunikasi dua hala yang memberi dan menerima maklum balas secara terbuka. Bagi Grunig (2001) model komunikasi interaktif atau symmetrical communication dilihat lebih efektif dan beretika daripada segi pengurusan komunikasi organisasi terutama dalam mewujudkan sebaran komunikasi secara berkesan. Namun ini tidak menidakkan keupayaan konsep komunikasi asymmetrical communication atau model komunikasi transmisi dalam menyampaikan komunikasi organisasi secara berkesan. Hal ini kerana menurut Grunig dan Dozier (2002) kedua-dua elemen komunikasi ini penting kerana organisasi perlu menguasai komunikasi dan pada masa yang sama memberi dan menerima tindak balas khalayak penting bagi memastikan keberkesanan komunikasi dan perhubungan yang dibina secara bersama antara mereka. Oleh itu, kedua-dua model komunikasi ini diterima dan relevan diaplikasikan dalam komunikasi strategik oleh organisasi.

Berdasarkan perbincangan ini terdapat empat faktor utama yang dikenal pasti yang menyumbang kepada keberkesanan penggunaan dan dua kritikan yang diutarakan terhadap amalan komunikasi strategik dalam pengurusan komunikasi organisasi. Dengan itu kita dapat melihat bagaimana komunikasi strategik memenuhi keperluan organisasi masa kini selaras dengan perubahan persekitaran dan segmen khalayak ekoran daripada perkembangan teknologi komunikasi yang berlaku. Walaupun terdapat kritikan yang memperlihatkan ketidaksesuaian dan kelemahan dalam komunikasi strategik, namun keberkesanan penggunaannya dalam pengurusan komunikasi organisasi tidak dapat disangkal.

\section{KESIMPULAN}

Bagi menyimpulkan secara keseluruhan perbincangan mengenai komunikasi strategik berdasarkan tiga fokus iaitu definisi, pendekatan dan pelaksanaannya dapatlah dinyatakan bahawa komunikasi strategik merupakan suatu proses komunikasi bertujuan yang digunakan oleh organisasi untuk mencapai matlamat dan sasaran dalam pelbagai konteks. Ini selari dengan konsep komunikasi strategik yang dinyatakan bahawa sesuatu komunikasi itu dianggap strategik sekiranya selari dengan matlamat dan sasaran yang ditetapkan oleh organisasi (Botan, 1997; Hallahan, 2007; Sandhu 2014). Bagi memastikan keberkesanan penyampaian, komunikasi strategik menyelaraskan aktiviti komunikasi secara sistematik menerusi proses perangkaan, pelaksanaan dan penilaian oleh organisasi. Dengan itu, kita dapat melihat bagaimana proses perancangan komunikasi dilakukan menerusi analisis SWOT yang dijalankan dan melaksana 
aktivitikomunikasi mengikut agenda dan pelan yang disediakan serta menilai keberkesanannya menerusi audit komunikasi oleh organisasi.

Selaras dengan sifatnya yang dinamik juga, komunikasi strategik berupaya mengadaptasi dengan perubahan persekitaran organisasi ekoran daripada perkembangan teknologi dan segmen khalayak yang pelbagai. Demikian, kita dapat melihat komunikasi strategik dipraktikkan secara berkesan dalam pengurusan komunikasi organisasi menerusi enam pendekatan utama seperti komunikasi pengurusan, komunikasi pemasaran, perhubungan awam, komunikasi teknikal, komunikasi politik dan informasi / kempen pemasaran sosial. Ini menjadikan komunikasi strategik begitu berkesan dan sesuai untuk diaplikasikan dalam membantu organisasi mengendalikan aktiviti komunikasi secara dalaman dan luaran. Oleh itu, ini boleh menyumbang kepada kejayaan organisasi untuk mencapai matlamat dan sasaran dengan jayanya menerusi pendekatan komunikasi selaras dengan empat teras kekuatan utama komunikasi strategik iaitu aktiviti yang dijalankan bersifat strategik, praktik atau amalan pengurusannya yang disifatkan sebagai terancang dan sistematik, penekanan komunikasi dalam mencipta makna serta sifatnya yang dinamik yang mampu menyesuaikan, menerbitkan pembaharuan dan kemajuan dengan segala bentuk perubahan komunikasi yang berlaku masa kini.

\section{RUJUKAN}

Argenti, P. A., Robert, A. H., \& Beck, K. A. (2005). The strategic communication imperative:. MIT Sloan Management Review, 46 (3). dari https://sloanreview.mit.edu/article/the-strategiccommunication-imperative/.

Botan, C. (1997). Ethics in strategic communication campaigns: the case for a new approach to public relations. Journal of Business Communication, 34, 188-202.

Farinloye, T., Wayne, T., Mogaji, E., \& Kuika Watat, J. (2020). Social media for universities' strategic communication. Strategic marketing of higher education in Africa. London: Routledge.

Gilpin, D. R., \& Murphy, P. J. (2008). Crisis management in a complex world. New York: Oxford University Press.

Grigorescu, A., \& Lupu, M. M. (2015). Integrated communication as strategic communication. Review of International Comparative Management, 16 (4), 479-490.

Grunig J.E., Grunig L.A. (2008) Excellence Theory in Public Relations: Past, Present, and Future. Dlm. Zerfass A., van Ruler B., Sriramesh K. (eds) Public Relations Research. VS Verlag für Sozialwissenschaften. https://doi.org/10.1007/978-3-531-90918-9_22

Hallahan, K., Holtzhausen, D., Van Ruler, B., Veri, D., \& Sriramesh, K. (2007). Defining Strategic Communication. International Journal of Strategic Communication, 1 (1), 3-35.

Hatch, M. J. (1997). Organization theory: Modern, symbolic, and postmodern perspectives. Oxford: Oxford University Press.

Herianto, A. S., \& Hassan, M. S. H. (1997). Strategi komunikasi untuk pembangunan pertanian yang mampan (analisis jurang PSA petani pada kempen strategik pengembangan). Jurnal Komunikasi, 13 \& 14, 137-148.

Holmstrom, S. (2005). Reframing public relations: the evolution of a reflective paradigm for organizational legitimization. Public Relations Reviews, 31 (4), 497-504.

Holtzhausen, D. R., \& Zerfass, A. (2013). Strategic communication: pillars and perspectives of an alternative paradigm. Dlm. A. Zerfass, L. Rademacher, \&S. Wehmeier (Eds.), Organisationskommunikation und public relations. (pp. 72-94.) Wiesbaden: Springer, 
Holtzhausen, D. (2014). Strategic communication. Dlm. Donsbach (Ed.). The International Encyclopedia of Communication ( $1^{\text {st }}$ ed.). New York: JohnWiley \& Sons, Ltd.

Johannensen, R. L. (1996). Ethics in human communication. (4 ${ }^{\text {th }}$ ed.). Illinois: Waveland Press.

Mahbob, M. H., Ali, N. A. S. M., Sulaiman, W. I. W., \& Mahmud, W. A. W. (2019). Komunikasi strategik dan peranannya untuk mewujudkan komunikasi berkesan dalam organisasi. Jurnal Komunikasi, 35 (2), 49-67.

Mahbob, M. H., Sulaiman, W. I. W., \& Mahmud, W. A. W. (2019). Pengaruh komunikasi strategik ke atas keberkesanan penyampaian mesej. Jurnal Komunikasi, 35 (3), 246 - 262.

McPhee \& Zaug (2000). The communicative constitution of organizations: a framework for explanation. Electronic Journal of Communication / La Revue Electronique de Communication, 10 (1-2), 1-16.

Miller \& Barbour. (Seventh Ed.). (2014). Organizational communication: approaches and processes. New York: Cengage Learning.

Mintzberg, H. (1979). The structure of organizations. Englewood Cliffs, NJ: Prentice-Hall.

Mintzberg, H. (1990). The design school: Reconsidering the basic premises of strategic communication management. Strategic Management, 11, 171-195.

Mogaji, E., Watat, J.K., Olaleye, S.A. and Ukpabi, D. (2021), Recruit, retain and report: UK universities' strategic communication with stakeholders on Twitter. Dlm. M.A. Camilleri (Ed.) Strategic corporate communication in the digital age, (pp. 89-114.). Bradford: Emerald Publishing Limited, Bingley, https://doi.org/10.1108/978-1-80071-264-520211006

Nothhaft, H., Werder, K. P., Verčič, D., \& Zerfass, A. (Eds.). (2020). Future directions of strategic communication. New York: Routledge.

Patterson, S. J., \& Radtke, J. M. (2012). Strategic communications for nomprofit organizations: seven steps to creating a successful plan. ( $2^{\text {nd }}$ ed.). United States of America: John Wiley \& Sons, Inc.

Porter, M. E. (1985). Competitive advantage: creating and sustaining superior performance. New York: Free Press.

Ries, A. \& Ries, L. (2003). The fall of advertising and the rise of PR. New York: Harper.

Sandhu, S. (2009). Strategic communication: An institutional perspective. International Journal of Strategic Communication, 3 (2), 72-92.

Shockley-Zalabak, P. (2015). Fundamentals of organizational communication: knowledge, sensitivity, skills, values. London: Pearson.

Tina Dacin, M., Goodstein, J., \& Richard Scott, W. (2002). Institutional theory and institutional change: Introduction to the special research forum. The Academy of Management Journal, 45 (1), 45-56.

Van Ruler, B. (2018). Communication theory: An underrated pillar on which strategic communication rests. International Journal of Strategic Communication, 12 (4), 367-381.

Verhoeven, P., Zerfass, A., Verčič, D., Moreno, Á., \& Tench, R. (2020). Strategic communication across borders: country and age effects in the practice of communication professionals in Europe. International Journal of Strategic Communication, 14 (1), 60-72.

Watson Wyatt. (2004). Connecting organizational communication to financial performance 2003/2004 communication ROI study. Worldwide Research Report, dari http://www.watsonwyatt. com/render.asp?catid=1\&id=12092. 